\title{
REPRESENTATIVES AND COMMITTEES OF THE SOCIETY
}

Representatives of the Society in the Division of Physical Sciences of the National Research Council:

1939-1940-Solomon Lefschetz, J. F. Ritt, Oystein Ore.

1940-1941-J. F. Ritt, Oystein Ore, G. C. Evans.

1941-1942-Oystein Ore, G. C. Evans, F. D. Murnaghan.

Representatives on the Council of the American Association for the Advancement of Science:

1941-H. E. Buchanan, H. J. Ettlinger.

1942-L. P. Eisenhart, R. G. D. Richardson.

Representatives on the Editorial Board of the Annals of Mathematics:

T. H. Hildebrandt, Saunders MacLane, G. T. Whyburn.

Representatives on the Editorial Board of the Duke Mathematical Journal:

F. J. Murray, Morgan Ward.

Representative on the American Year Book:

J. F. Ritt.

Representative on the Sectional Committee on Standards for Graphical Presentation sponsored by the American Society of Mechanical Engineers:

W. H. Roever.

Representative on the Joint Committee on Engineering Statistics sponsored by the American Society of Mechanical Engineers and the American Society for Testing Materials:

A. A. Bennett.

Representative on the Joint Committee for the Development of Statistical Applications in Engineering and Manufacturing:

E. V. Huntington.

Colloquium Speakers:

1940-G. T. Whyburn.

1941-Oystein Orè.

1942-R. L. Wilder.

1943-E. J. McShane.

Committee on Gibbs Lecturers:

N. H. McCoy, H. P. Robertson, J. L. Synge.

Gibbs Lecturers:

1923-M. I. Pupin. 1929-Irving Fisher. 1936-H. N. Russell.

1924-Robert Henderson. 1930-E. B. Wilson. 1937-C. A. Kraus.

1925-James Pierpont. 1931-P. W. Bridgman. 1939-Theodore von Kármán.

1926-H. B. Williams. 1932-R. C. Tolman. 1941-Sewall Wright.

1927-E. W. Brown. 1934-Albert Einstein.

1928-G. H. Hardy. 1935-Vannevar Bush. 
Committee on Society Visiting Lectureship:

G. D. Birkhoff, G. A. Bliss, E. R. Hedrick.

Visiting Lecturers:

1927-1928-Constantin Carathéodory, University of Munich.

1928-1929-Hermann Weyl, Zurich Technical School.

1929-1930-Enrico Bompiani, University of Rome.

1930-1931-Wilhelm Blaschke, University of Hamburg.

1931-1932-R. L. Moore, University of Texas.

1936-1937-Thirukkannapuram Vijayaraghavan, University of Dacca.

\section{Committee on the Moore Fund:}

R. D. Carmichael, Arnold Dresden, 'T. H. Hildebrandt

\section{Committee on Publication of Moore Manuscript:}

R. W. Barnard, E. W. Chittenden, L. M. Graves, T. H. Hildebrandt, M. H. Ingraham.

\section{Committee on Printing Contracts:}

D. R. Curtiss, M. H. Ingraham, C. C. MacDuffee.

\section{Committee on Publicity:}

R. M. Foster, Saunders MacLane, G. B. Price, J. B. Rosser, J. M. Thompson, R. J. Walker.

\section{Committees to Select Hour Speakers:}

For Annual and Summer Meetings: M. H. Ingraham, J. R. Kline, M. H. Stone.

For Eastern Sectional Meetings: C. R. Adams, Salomon Bochner, T. R. Hollcroft.

For Western Sectional Meetings: W. L. Ayres, T. H. Hildebrandt, W. J. Trjitzinsky.

For Far Western Sectional Meetings: G. C. Evans, T. M. Putnam, T. Y. Thomas.

\section{Committee on Places of Meetings:}

W. B. Carver, E. W. Chittenden, A. B. Coble.

\section{War Preparedness Committee:}

General Chairman: Marston Morse.

Subcommittee on Research: Harry Bateman, Dunham Jackson, E. J. McShane, M. H. Stone, J. H. Van Vleck, Norbert Wiener, S. S. Wilks.

Subcommittee on Preparation for Research: B. O. Koopman, R. E. Langer, Hans Lewy, F. D. Murnaghan, H. P. Robertson, M. H. Stone.

Subcommittee on Education for Service: R. S. Burington, J. L. Coolidge, H. B. Curry, E. C. Goldsworthy, F. L. Griffin, W. L. Hart, M. H. Ingraham, E. J. Moulton.

Subcommittee on Supply and Demand for Mathematicians: Harry Bateman, E. T. Bell, G. C. Evans, T. Y. Thomas, W. M. Whyburn.

Consultants: Aeronautics-Harry Bateman. Ballistics-John von Neumann, W. T. Reid. Computation-Norbert Wiener. Cryptanalysis-A. A. Albert, H. T. Engstrom, W. A. Hurwitz, Solomon Kullback, Oystein Ore. Industry-T. C. Fry. Probability and Statistics-S. S. Wilks. 

ticians:

Emergency Executive Committee of the International Congress of Mathema-

G. D. Birkhoff, Einar Hille, M. H. Ingraham, J. R. Kline, Marston Morse, R. G. D. Richardson, M. H. Stone.

\section{FORMER PRESIDENTS}

J. H. Van Amringe, 1889-1890.

Emory McClintock, 1891-1894.

G. W. Hill, 1895-1896.

Simon Newcomb, 1897-1898.

R. S. Woodward, 1899-1900.

E. H. Moore, 1901-1902.

T. S. Fiske, 1903-1904.

W. F. Osgood, 1905-1906.

H. S. White, 1907-1908.

Maxime Bôcher, 1909-1910.

H. B. Fine, 1911-1912.

E. B. Van Vleck, 1913-1914.

E. W. Brown, 1915-1916.
L. E. Dickson, 1917-1918.

Frank Morley, 1919-1920.

G. A. Bliss, 1921-1922.

Oswald Veblen, 1923-1924.

G. D. Birkhoff, 1925-1926.

Virgil Snyder, 1927-1928.

E. R. Hedrick, 1929-1930.

L. P. Eisenhart, 1931-1932.

A. B. Coble, 1933-1934.

Solomon Lefschetz, 1935-1936.

R. L. Moore, 1937-1938.

G. C. Evans, 1939-1940.

\section{ENDOWMENT FUND}

In 1923 an Endowment Fund was collected to meet the greater demands on the Society's publication program caused by the ever increasing number of important mathematical memoirs. Of this fund, which now amounts to some $\$ 60,000$, a considerable proportion was contributed by members of the Society.

\section{SPECIAL FUNDS}

\section{The Bôcher Memorial Prize.}

This prize was founded in memory of Professor Maxime Bôcher. It is awarded every five years for a notable research memoir in analysis which has appeared during the preceding five years in a recognized journal published in the United States or Canada; the recipient must be a member of the Society, and not more than fifty years old at the time of publication of his memoir.

First (Preliminary) Award, 1923: To G. D. Birkhoff, for his memoir Dynamical systems with two degrees of freedom.

Second Award, 1924: To E. T. Bell, for his memoir Arithmetical paraphrases, and to Solomon Lefschetz, for his memoir On certain numerical invariants with applications to abelian varieties.

Third Award, 1928: To J. W. Alexander, for his memoir Combinatorial analysis situs.

Fourth Award, 1933: To Marston Morse, for his memoir The foundations of a theory of the calculus of variations in the large in m-space, and to Norbert Wiener, for his memoir Tauberian theorems.

Fifth Award, 1938: To John von Neumann, for his memoir Almost periodic functions and groups. 